\title{
Assessment of Honeybee Diseases, Enemies and Their Control Mechanisms in Gondar Zuria District, North Gondar, Ethiopia
}

\author{
Assefa Adane, Barkot Yonis, Tsehaynesh Fentahun \\ Department of Animal Production and Extension, College of Veterinary Medicine and Animal Sciences, University of Gondar, Gondar, \\ Ethiopia
}

Email address:

asselal448@gmail.com (A. Adane), assefa.adane@uog.edu.et (A. Adane)

\section{To cite this article:}

Assefa Adane, Barkot Yonis, Tsehaynesh Fentahun. Assessment of Honeybee Diseases, Enemies and Their Control Mechanisms in Gondar Zuria District, North Gondar, Ethiopia. American Journal of Plant Biology. Vol. 5, No. 4, 2020, pp. 105-109.

doi: 10.11648/j.ajpb.20200504.15

Received: June 15, 2020; Accepted: June 28, 2020; Published: November 27, 2020

\begin{abstract}
The study was conducted in Gondar Zuria District, North Gondar to assess honeybee disease, enemies and their control mechanisms. For this study three peasant associations were selected through purposive sampling. From each peasant association 20 respondents were selected by systematic random sampling and data collected using semi-structured questioner, observation; and were analyzed using descriptive statistics. The result revealed that disease like Nosema (43.3\%), Chalk brood (30.0\%), Varroa mites $(8.3 \%)$ and bee paralysis $(18.3 \%)$ and from enemies such as ant $(43.3 \%)$, bird (16.7\%), termites $(28.3 \%)$ and wildcat (11.7\%) were found in the study area, However, farmers use different control mechanism like cleaning the hive, keeping the colony strong, putting of ash on their nest and regular inspection of the hive the apiary site should be free from those chemical's like insecticide and herbicide sprayed on foraging flowers and beekeepers should take some measures or negotiate with scrap growers and problem is observed poor traditional system of management like watering feeding and health care management most of the beekeepers is traditionally. There are three types of beekeeping systems; traditional $(80.0 \%)$, transitional (16.7\%) and modern (3.3\%), but traditional hive is more affected by disease than other. All of the respondent in the study area there are number of challenges for honeybee. In general honey bee production potential of farmers in the area is constrained by various challenges especially by bee diseases and enemies. The most important bee disease in the area was found Nosema and the prime enemies are ant those impede productivity of honey bee in the area. There should be given good extension service and sustainable awareness creation through various means of incentives to empower beekeepers for controlling of bee diseases and enemies by coordinating their indigenous knowledge with the scientific methods.
\end{abstract}

Keywords: Control Mechanism, Disease, Enemies, Honeybee

\section{Introduction}

Ethiopia has the largest honeybee population and owns big potential of honey production. Owing to its varied ecological and climatic condition, Ethiopia is the largest honey producer in Africa and $10^{\text {th }}$ largest honey producer all over the world. In addition, there is a considerable amount of bee wax product. However, the total honey produced in the country only small amount is marketed [1]. There has longstanding beekeeping practice and endowed with huge apicultural resource and has been an integral part of other agricultural activity, where about one million households keep honeybees.
More than 5.15 million hived honeybee populations are in the country [2].

Farmers use different control mechanism in order to protect their honeybees from disease enemies from those control mechanism removing of infected comb, cleaning of the apiary site, disinfect the hive, maintain adequate food supply, remove unused and empty comb etc are some of the control mechanism [3]. Amhara region, as one of the potential region in the country, has colony resource potential. It contains $23 \%$ of bee colonies and $22.8 \%$ of the total honey production in the country [4]. However, the success of apicultural activity depends on biotic and environmental 
factors proffered by the ecosystem. Honeybee disease and enemies have identified as one of major biotic factors affecting the successful beekeeping practice [5]. Because of the aforementioned reasons the study was conduct on honeybee disease and enemies that affecting honeybee productivity and their traditional control mechanisms in Gondar Zuria District. The objective of this study is to assess honeybee disease, enemies and their control mechanism.

\section{Methodology}

The study was conducted in Gondar Zuria District in North Gondar Zone, Ethiopia. The District is located at 37²4'24"E- $37^{\circ} 45^{\prime} 43^{\prime \prime} \mathrm{E}$ and $12^{\circ} 7^{\prime} 23^{\prime \prime} \mathrm{N}-12^{\circ} 39^{\prime} 24^{\prime \prime} \mathrm{N}$ and its estimated total area is $1286.76 \mathrm{~km}^{2}$. In the District, temperature ranges between $14-20^{\circ} \mathrm{C}$ with the mean annual temperature of $17.9^{\circ} \mathrm{C}$. Rainfall ranges between $1030-1223 \mathrm{~mm}$ with the mean annual of $1100 \mathrm{~mm}$. The District has an estimated total population of $231,382(117,414$ were males and 113,698 were females). About $10.24 \%$ of its population is urban dweller, which is less than the zone average of $14.1 \%$. The rural area constitutes 40,551 households, with an estimated area of 1,286.76 square kilometers [6]. Mixed farming system characterizes the agricultural production system of the District.

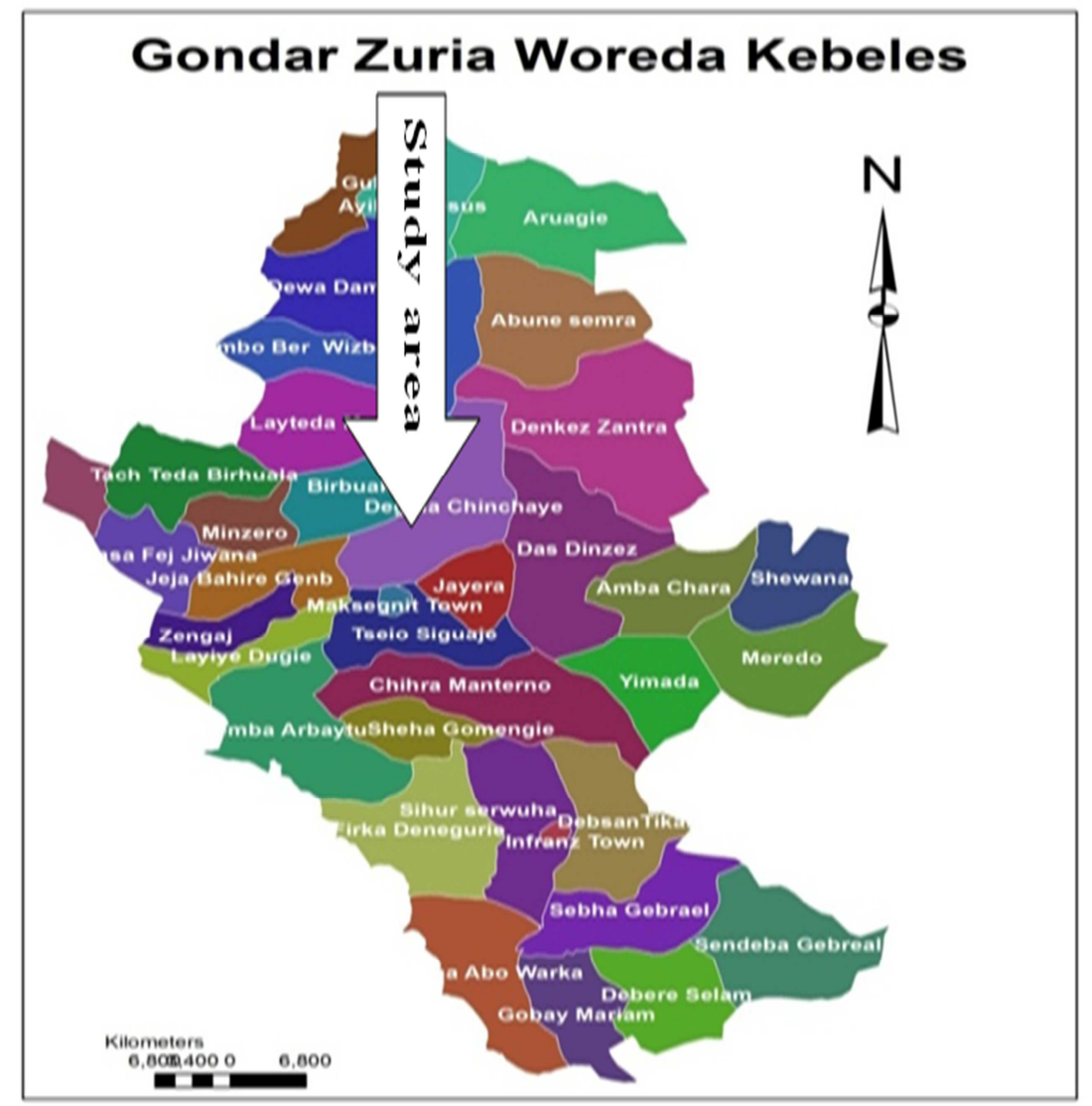

Figure 1. Map of Gondar Zuria Distinct.

Three peasant associations were selected purposively (Das Dinzaz, Degola and Chinchaye) because of relatively large number of participants in beekeeping and potential for beekeeping by making consultation with agricultural office expertise of the districts. Total of 60 households selected $(20$ from each peasant association) respondents were selected by systematic random sampling to collect primary data. Both quantitative and qualitative data were collected from primary as well as secondary sources. Household survey through the help of prepared semi-semi-structured interview was employed to collect valuable data from the sampled respondents. In addition, direct personal observation was carried out to observe the real situation near by the apery-site of sample respondents.
Focus group discussion was conducted in the study area with 8 individuals' purposively selected model honey bee producers who are believed to have background about bee keeping concerning the scientific as well as indigenous knowledge. Key informant interview was employed to supplement the data collected through household survey with study district beekeeping expert, developing agent (DAs) of the study area, and some individual beekeeper farmers. The data collected was organized in SPSS version 20 and analyzed and summarized by using descriptive statics, like frequency, mean, and percentage and was presented in the form of tables and graphs. Moreover, qualitative data was analyzed through narration and categorization of data obtained from the perception of the sample respondents to 
support the quantitative result of descriptive analysis.

\section{Results and Discussion}

\subsection{Socio Economic Characteristics of Household}

Table 1. Sex, religion and marital status.

\begin{tabular}{llll}
\hline Variables & Categories & Frequency & Percent \\
\hline \multirow{2}{*}{ Sex } & Male & 51 & 85.0 \\
& Female & 9 & 15.0 \\
Religion & Orthodox & 55 & 91.7 \\
& Muslim & 3 & 5.0 \\
& Others & 2 & 3.3 \\
Marital status & Single & 8 & 13.3 \\
& Married & 50 & 83.3 \\
& Divorced & 2 & 3.3 \\
Educational & Illiterates & 18 & 30 \\
level & Elementary education & 24 & 40 \\
& Secondary education & 13 & 22 \\
& Higher education & 5 & 8 \\
\hline
\end{tabular}

From the total respondents $85 \%$ were male and $15 \%$ were female. This implies that there is low level of female participation in bee keeping in the study area based on FGD and key informant due to traditional beliefs and females give more emphasis for household activity rather than keeping bees. Similarly, [7] reported that in Ethiopia traditional beekeeping is man's job due to cultural taboo. According to response of the respondent's majority of sample households in the study area are orthodox (91.7\%), Muslim (5.0\%) and others (3.3\%) religion followers respectively. This indicates that most of the respondents are orthodox religion follower this might not have effect on honey bee keeping practices. As shown in table 1 of the total sample households married $83.3 \%, 13.3 \%$ and $(3.3 \%)$ are married, single and divorced respectively. This indicates that majority of the sample respondents are get married this might have effect on honey bee production effort of the household due to sharing of labour, resource and effort.

Based on the response of the respondents of the total sample households $41 \%$ have learned up to primary education. Whereas $(30 \%)$ of the respondents have not received any formal education (illiterate). Minimal proportion of the respondents $(8 \%)$ has higher educational level (Table 1). This implies that majority of sample respondents to some extent have acquired formal education that might enable them to apply in honeybee production and management activities by coordinating with their indigenous knowledge. The overall mean of the respondents' age were 40.68 participated in the bee keeping. This implies that most of the respondents are in age range of labour force able to take part actively in honey bee production, product processing and marketing. On average household family size were 4.53. This might be opportunity for the households to practice honey bee production activities in good manner because there could not be shortage of labour.

Table 2. Age and family size.

\begin{tabular}{|c|c|c|c|c|}
\hline Variables & Minimum & Maximum & Mean & Std. Deviation \\
\hline age of $\mathrm{HH}$ head & 25.0 & 56.0 & 40.683 & 8.7769 \\
\hline Family size & 1 & 9 & 4.53 & 2.213 \\
\hline Numbers of livestock & 1 & 32 & 11.12 & 8.43 \\
\hline Numbers of honey bee hive & 0 & 27 & 8.68 & 6.575 \\
\hline
\end{tabular}

As shown in table 2 the overall average livestock ownership of sample respondents is 11.12 . This opined that most of the households have good status in livestock keeping practices and they can get more benefit from livestock production in the study area. According to the above table the overall mean of honey bee hive kept by the respondent 8.68 . In this regard one can recognize there is high level of bee keeping and owning of more honey bee hives in the study area.

\subsection{Honey Bee Keeping Practice}

The study result revealed that $35.0 \%$ of respondents started keeping bee hives through bought from other producer. The other $(31.7 \%)$ and $33.3 \%$ of respondent established bee keeping through catching swarm and getting hive from their parent respectively. In this regard the source of bee hive for majority of the respondents is buying from other producer or agricultural bee multiplication center for expanding the numbers of their bee colony. Depending on the result farmers keep honeybee for the purpose of income generation $63.3 \%$ (Table 4). As aforementioned major purpose of honey bee keeping in the study area is for income generation this is because of many reasons such as by selling honey, bee colony, bee wax as forwarded by FGD participants and key informants. Based on the respondent, about $80.0 \%$ of beehive is traditional, $16.7 \%$ transitional and 3.3\% modern beehive. This is in line with the report of [8], more than $99 \%$ of bees are still kept in traditional hives with its various limitations. Majority of the respondents kept their bee hives in their backyard in well-arranged manner and keeping the site free of any enemies.

Table 3. Purpose, source, types and placement of hive.

\begin{tabular}{llll}
\hline Variable & Categories & Frequency & Percent \\
\hline \multirow{4}{*}{$\begin{array}{l}\text { Purpose of } \\
\text { bee keeping }\end{array}$} & As source of additional income & 38 & 63.3 \\
& As recreational & 19 & 31.7 \\
Source of & Others & 2 & 3.3 \\
honey bee & Carent & 1 & 1.7 \\
colonies & Buying & 21 & 33.3 \\
Types of & Traditional & 19 & 31.7 \\
hive & Transitional & 20 & 35.0 \\
& Modern & 48 & 80.0 \\
\multirow{2}{*}{$\begin{array}{l}\text { Placement } \\
\text { of hive }\end{array}$} & Back yard & 10 & 16.7 \\
& Under the eave & 2 & 3.3 \\
& Hanging on the tree near the & 39 & 65.0 \\
& home stead & 4 & 6.7 \\
\hline
\end{tabular}




\subsection{Honey Bee Disease, Enemies and Their Control Mechanisms}

\subsubsection{Honeybee Disease}

Majority of the respondents opined that there is honeybee disease occurrence in their hive this can be recognized by different signs and condition that happened in the hive and the remaining respondent outside during inspection. The diseases that occur in the study area are during prolonged dry period like Nosema, Chalk brood, varroa mites and bee paralysis disease. Nosema $43.3 \%$, Chalk brood $30.0 \%$, Varroa mites $8.3 \%$ and $18.3 \%$ bee paralysis disease (Table 4) as pointed out by respondents are the most important diseases for honeybees in the area. Therefore, the Farmer use traditional control mechanism such as keeping the colony strong by organizing two week colony's, keep their from wet area and removing the infected bee colonies. The result agrees with the finding of [9] indicated that Nosema can be controlled by keeping colonies as strong as possible and removing possible cause of stress.

Table 4. Types of bee disease.

\begin{tabular}{lll}
\hline Types of bee disease & Frequency & Percent \\
\hline Nosema & 26 & 43.3 \\
Paralyses of colony & 11 & 18.3 \\
Chalk broad & 18 & 30.0 \\
Varroa mites & 5 & 8.3 \\
Total & 60 & 100.0 \\
\hline
\end{tabular}

Chalk brood disease is the other most important disease caused by fungus ascophreap is which attack workers and drones. Bees that affected by this disease shows the larvae die early and the larvae seems like chalk. As pointed out by key informants in order to reduce the effect of Chalk brood disease on bee production farmers have to clean the brood nest and burning infected brood comb to control the disease. The third disease which have significance influence to honeybee is bee paralysis disease which is caused by chronic paralysis virus and show bees fail to fly, trembling of wing and body crowing on the ground and dislocating wing but Disease happen rarely when there is scarcity of flora but farmers removing the infected bees and cleaning the hive. The result agree with the finding of [10] who indicated that the existence of honey bee disease strongly affect the honey bees and hive products.

\subsubsection{Enemies of Honeybee}

Number of enemies attacks honeybee and cause damage to the colonies and hive product due to improper management and the apiary site. Based on the cause on the honeybees and hive products, the major predators exist in the study area identified and prioritized by the respondents and indicated in table 5 below. Hence, ant is found to be the most serious problem as compared to others. Next to ant, bird, termites and wildcat local name (Shelemitmat) are indicated serious problems in decreasing order.
Table 5. Types of bee enemies.

\begin{tabular}{lll}
\hline Types of enemies & Frequency & Percent \\
\hline Ant & 26 & 43.3 \\
Termites & 17 & 28.3 \\
Birds & 10 & 16.7 \\
Wild cat & 7 & 11.7 \\
Total & 60 & 100.0 \\
\hline
\end{tabular}

Based on the result obtained from respondents, enemies are the major challenge next to disease in the study area similar result reported by [11], one of the most constraints for honey bee and beekeepers are the presence of enemies. From above result, $43.3 \%$ of the respondent observe ant in their hive, bee keepers recognized that their bees could suffer from ant which result in death of adult honey bee in the hive and absconding of bee colonies. In this case the beekeepers use; putting ash around the hive stand, pour hot water in to the ants nest, dipping the nest of the hive with stone and mud, smoking like sheep and men hair, putting protective plastic under the hive stand, close the cracks and holes by mud, spray soap solution, brushing the hive with local plants like "Tenadam" and onion and putting tree leaves near the hive stand to control the effect of ant on bee and to restrict the movement of ant from its nest to the honey bee hive it is found in line with the finding of [12]. The next enemy which is found in the area is termite $(28.3 \%)$. which seems ant and cause the bees to abscond from the hive. The third enemies in this area is birds $(16.7 \%)$ which attacks mainly the worker bee during transport water, orientation flight, nectar and water gathering and during guard duty. So farmers use rob local name "Wonchif" to produce noise for brides, killing one hunter and hanging it near the hive and destroy their nest.

\subsubsection{Disease with Seasonal Variation and Chemical Utilization Used for Crop}

According to the above table the respondent of the study area said about disease in seasonal variation (65.0\%) respondent answers yes and the others (35.0\%) of the respondent answer no. The respondent that answers yes also said Nosema during dry season and stress times and termites in rainy season and nutritional imbalance.

Table 6. Disease with seasonal variation and chemical utilization.

\begin{tabular}{llll}
\hline Variable & Categories & Frequency & Percent \\
\hline Disease with seasonal & No & 21 & 35.0 \\
variation & Yes & 39 & 65.0 \\
Chemical utilization & Yes & 60 & 100.0 \\
used for crop & No & 0 & 0 \\
\hline
\end{tabular}

Based on the above table the result obtained from respondent's chemical utilization is the major challenge next to disease and enemies in the study area. It is more serious under developing country. When intensive agricultural exercise are practiced using chemical like insecticides and herbicides sprayed on crop for the purpose of insect and other pest control it leads to poisoning of honey bee. And when the bee foraging that crops flower sprayed insecticides and herbicides, may leads to death or weakness of the bee colony. 


\section{Conclusion}

Beekeeping is dominantly operated most importantly by males and there were few of women beekeeper involvement. Most prime sources of honeybee colonies are market, swarm catching and other colony producers. Large number of producers use traditional hive due to its easy accessibility of material by farmers and lower proportion of the farmers use transitional and modern hive. Honeybee production is constrained by most important disease like Nosema; Chalk brood, Varroa mites and bee paralysis disease. However, Nosema which is a serious disease, causing the bees restlessness and dysentery and controlled through keeping the colony strong and keeping their bee from study area. Chalk brood which making the brood seems like chalk and controlled by cleaning the brood nest and burning the infected brood comb. Varroa mites can be seen with necked eye as a small red or brown spot on the bee's thorax. The disease, which is found in the study area, is bee paralysis that causing the bee fails to fly and trembling of wing and bodies and controlled by cleaning of the hive. In addition of disease, there are enemies which, is found in the study area like; predator (ant, bride, termite and wild cat). From that predator the respondents rank first for ant which results in death of adult bee and absconding of the colony and it controlled by putting ash on the hive stand. The second is Termites which, cause abscond and controlled by putting ash. The third predator is wild cat which, cause destruction of hive and can be controlled by standing dangerous bee. The last Birds which attacks worker bee and controlled by destroying their nest. Generally, those disease and enemies are happen due to improper management of hive.

\section{Recommendation}

Based on the above conclusive remarks the following recommendations were forwarded as valuable insight for concerned body to improve honey bee production and productivity.

1. Awareness creation through mass extension should be practiced for beekeepers how to control bee disease and enemies in order to reduce the severity and production loss.

2. There should be sustainable support services through training and other empowering mechanisms so as to strengthen beekeepers capability by linking their traditional mode of controlling bee diseases and enemies with the scientific methods.

3. There should be enhanced research on developing technology from local available materials for promotion of honey bee enemy protection method and organizing apiary demonstration.

\section{References}

[1] EEPD, 2006. Export of honey bee and bee wax, draft report, EEPD. Minister of trade and industry, Addis Ababa, Ethiopia.

[2] Adgaba A, Al Ghamdi AG, Shenkute S, Ismaiel S, Al Kahtani Y, Tadess MJ, Ansari W, Abebe MQ, Abdulaziz A 2014. Socio economic analysis of beekeeping and determinants of box hive technology adoption in the kingdom of Saudi Arabia. J. Anim. Plant Sci. 24 (6): 1876-1884.

[3] Amsalu Belay, 2001. Bee management training manual Holeta research center.

[4] C. S. A, (Central Statistics Authority), 2014. Potential of honey bee production in Amhara region Ethiopia.

[5] Olyerinde and Ande, 2009. Distribution and impact of honey bee pests on colony developments in Kwara State, Nigeria. J. Agric. Soc.

[6] CSA (Central Statistics Authority). 2016. Agricultural sample survey. Livestock and livestock characteristics. Volume II. Addis Ababa, Ethiopia.

[7] Hartman, I, 2004. The management of resource and marginalization in bee keeping societies of south west Ethiopia. Paper submitted to the conference: Bridge scale and Epistemology, Alexandria. P. I.

[8] Gezahegn Taddese, 2001. Marketing of honey and bee wax in Ethiopia: past, present and perspective feature. Pp. 78-88 proceeding of the third national Annual conference of the Ethiopia beekeepers association (EBA). September 3-4, Addis Ababa, Ethiopia.

[9] Abrol D. P, 2001. Honeybee disease and their management. Proceeding of the Second National Annual Conference of Ethiopia Beekeepers Association (EBA). September 10-11, Addis Ababa, Ethiopia.

[10] Workneh, 2007. National apiculture strategy document. Holeta Research Center.

[11] Dessalegn Belay, 2001. Same major of and predator of honeybee in Ethiopia. Holeta bee research center. 